(Supporting Information)

\title{
Hydrogen evolution electrocatalyst design: turning inert gold into active catalyst by atomically precise nanochemistry
}

\author{
Yingwei $\mathrm{Li}^{1, \uparrow}$, Site $\mathrm{Li}^{1, \uparrow}$, Anantha V. Nagarajan ${ }^{2, \dagger}$, Zhongyu Liu ${ }^{1}$, Sarah Nevins ${ }^{1}$, Yongbo Song ${ }^{1,3^{*}}$, \\ Giannis Mpourmpakis ${ }^{2 *}$, and Rongchao Jin ${ }^{1 *}$ \\ ${ }^{1}$ Department of Chemistry, Carnegie Mellon University, Pittsburgh, PA 15213; \\ ${ }^{2}$ Department of Chemical Engineering, University of Pittsburgh, Pittsburgh, PA 15261; \\ ${ }^{3}$ School of Biomedical Engineering, Research and Engineering Center of Biomedical Materials, Anhui Medical \\ University, Hefei, Anhui 230032, China. \\ These authors contribute equally to the work. \\ (*Email: rongchao@andrew.cmu.edu; gmpourmp@pitt.edu; ybsong860@ahmu.edu.cn)
}

\section{Experimental}

\section{Chemicals}

Tetrachloroauric (III) acid $\left(\mathrm{HAuCl}_{4} \cdot 3 \mathrm{H}_{2} \mathrm{O}, 99.999 \%\right.$ metal basis, Aldrich), silver nitrate $\left(\mathrm{AgNO}_{3},>99.0 \%\right.$, Aldrich), tetraoctylammonium bromide (TOAB, > 98\%, Alfa Aesar), sodium borohydride $\left(\mathrm{NaBH}_{4}, 99.99 \%\right.$ metal basis, Aldrich), 1-adamantanethiol ( $\mathrm{SC}_{10} \mathrm{H}_{15}, 95 \%$, Aldrich), 2-phenylethanethiol $\left(\mathrm{HSC}_{2} \mathrm{H}_{4} \mathrm{Ph}, 99 \%\right.$, Aldrich), L-glutathione reduced (HSG, 98.0\%, Aldrich), tetrahydrofuran (THF), methanol, ethanol, dichloromethane $\left(\mathrm{CH}_{2} \mathrm{Cl}_{2}\right)$, toluene, acetone, hexane and acetonitrile (HPLC grade for all solvents) were used as received.

\section{Syntheses}

$\mathbf{A u}_{36} \mathbf{A g}_{2}\left(\mathbf{S C}_{10} \mathbf{H}_{15}\right)_{18}: 90.9 \mathrm{mg} \mathrm{HAuCl} \cdot 3 \mathrm{H}_{2} \mathrm{O}, 3.9 \mathrm{mg} \mathrm{AgNO}$ ( $\mathrm{Au}: \mathrm{Ag}$ molar ratio = 10:1), and $120 \mathrm{mg}$ 1adamantanethiol were mixed together in $15 \mathrm{~mL}$ methanol for $30 \mathrm{~min}$. After centrifugation, the dark orange precipitate was dissolved in $15 \mathrm{~mL}$ THF for $30 \mathrm{~min}$, before an aqua solution of $140 \mathrm{mg} \mathrm{NaBH} 4$ in $5 \mathrm{~mL}$ icecold nanopure water was added immediately. The reaction was continued for $3 \mathrm{~h}$, and then the solvent was evaporated. The product was washed by methanol thoroughly and extracted by toluene. The $\mathrm{Au}_{36} \mathrm{Ag}_{2}\left(\mathrm{SC}_{10} \mathrm{H}_{15}\right)_{18} \mathrm{NCs}$ were further purified by crystallization via layer diffusion of methanol into the toluene solution within 2 days.

[A $\left.\mathbf{A u}_{25}\left(\mathbf{S C}_{2} \mathbf{H}_{4} \mathbf{P h}\right)_{18}\right]^{-}: 80 \mathrm{mg} \mathrm{HAuCl}{ }_{4} \cdot 3 \mathrm{H}_{2} \mathrm{O}, 130 \mathrm{mg} \mathrm{TOAB}$, and $135 \mu \mathrm{L} \mathrm{HSC} \mathrm{H}_{2} \mathrm{H}_{4} \mathrm{Ph}$ were mixed in $15 \mathrm{~mL}$ THF for $30 \mathrm{~min}$, before an aqua solution of $80 \mathrm{mg} \mathrm{NaBH}_{4}$ in $5 \mathrm{~mL}$ ice-cold nanopure water was added immediately. The reaction was continued for $24 \mathrm{~h}$ before the solvent was evaporated. The product was washed by methanol thoroughly and extracted by acetonitrile.

$\mathbf{A u}_{38}\left(\mathbf{S C}_{2} \mathbf{H}_{4} \mathbf{P h}\right)_{24}: 200 \mathrm{mg} \mathrm{HAuCl}{ }_{4} \cdot 3 \mathrm{H}_{2} \mathrm{O}$ and $650 \mathrm{mg} \mathrm{HSG}$ were mixed in $20 \mathrm{~mL}$ acetone for $20 \mathrm{~min}$, then cooled to $0{ }^{\circ} \mathrm{C}$ in an ice bath for $20 \mathrm{~min} .190 \mathrm{mg} \mathrm{NaBH}_{4}$ in $5 \mathrm{~mL}$ ice-cold nanopure water was rapidly added 
to the suspension. After $20 \mathrm{~min}$, the acetone solution was discarded and $6 \mathrm{~mL}$ water was added to dissolve the $\mathrm{Au}_{n}(\mathrm{SG})_{m}$ again, followed by adding $0.3 \mathrm{~mL}$ ethanol, $2 \mathrm{~mL}$ toluene, and $2 \mathrm{~mL} \mathrm{HSC}_{2} \mathrm{H}_{4} \mathrm{Ph}$. The di-phased solution was submitted to ligand exchange at $80{ }^{\circ} \mathrm{C}$ for $\sim 24 \mathrm{~h}$. The organic phase was washed by methanol thoroughly and extracted by $\mathrm{CH}_{2} \mathrm{Cl}_{2}$.

\section{Characterization}

UV-vis spectra of the NCs were measured on a Hewlett-Packard Agilent 8453 diode array spectrophotometer at room temperature. MALDI mass spectrometry was performed on a PerSeptive Biosystems Voyager DE super-STR time-of-flight (TOF) mass spectrometer.

\section{X-ray crystallography of $\mathrm{Au}_{36} \mathrm{Ag}_{2}\left(\mathrm{SC}_{10} \mathrm{H}_{15}\right)_{18}$}

A suitable crystal was mounted onto a MiTeGen capillary with fluorolube and performed on a STOE STADIVARI diffractometer equipped with $\mathrm{CuK} \alpha \mathrm{X}$-ray source $(\lambda=1.54186 \AA)$. The crystal was kept at 120(2) K during data collection. Using Olex $2,{ }^{1}$ the structure was solved with the olex 2. solve $^{2}$ structure solution program using Charge Flipping and refined with the ShelXL ${ }^{3}$ refinement package using Least Squares minimization. All the $\mathrm{Au}, \mathrm{Ag}$, and $\mathrm{S}$ atoms were found directly. Remaining non-hydrogen atoms were generated via subsequent difference Fourier syntheses. All the non-hydrogen atoms were refined anisotropically. All the hydrogen atoms were set in geometrically calculated positions and refined isotropically using a riding model.

\section{Electrochemical Measurements}

The electrochemical tests were carried out on a CHI 620C electrochemical station using a three-electrode system with a glassy carbon rotation disc electrode (RDE) (PINE, $5 \mathrm{~mm}$ diameter, $0.196 \mathrm{~cm}^{2}$ ) as working electrode. A platinum wire and $\mathrm{Ag} / \mathrm{AgCl}$ electrode (saturated $\mathrm{KCl}$ ) were used as the counter and reference electrodes, respectively. The catalyst ink is prepared by mixing isopropyl alcohol and catalyst with ultrasonic mixing for about $30 \mathrm{~min}$. To prepare the working electrode, the ink was transferred onto the GC working electrode (catalyst loading of $\sim 0.2 \mathrm{mg} \mathrm{cm}^{-2}$ ), followed by $5 \mu \mathrm{L} 0.02 \mathrm{wt} \%$ Nafion (diluted from 5 wt $\%$ Nafion, Sigma-Aldrich). The electrolyte $\left(0.5 \mathrm{M} \mathrm{H}_{2} \mathrm{SO}_{4}\right)$ was degassed by bubbling $\mathrm{N}_{2}$ for $30 \mathrm{~min}$ before the electrochemical tests. The polarization curves were obtained by sweeping the potential from 0 to $-0.8 \mathrm{~V}$ versus $\mathrm{Ag} / \mathrm{AgCl}$ at room temperature with a sweep rate of $5 \mathrm{mV} \mathrm{s}^{-1}$ at a rotation rate of $1600 \mathrm{rpm}$. All the data were recorded without $i R$.

\section{Computational Methods}

Electronic Structure and theoretical photo-absorption spectra calculations: All DFT electronic structure and optical spectra calculations were performed using the Perdrew-Burke-Ernzerhof (PBE) ${ }^{4}$ functional and def2-SV $(\mathrm{P})^{5}$ basis set, accelerated with the resolution of identities (RI) ${ }^{6,7}$ approximation. The calculations were performed in the computational package Turbomole v7.21. ${ }^{8}$ The initial geometries of $\mathrm{Au}_{25}\left(\mathrm{SCH}_{3}\right)_{18}{ }^{-}$and $\mathrm{Au}_{38}\left(\mathrm{SCH}_{3}\right)_{24}$ were obtained from reported crystal structures ${ }^{9,10}$ and that of 
$\mathrm{Au}_{36} \mathrm{Ag}_{2}\left(\mathrm{SCH}_{3}\right)_{18}$ was obtained from the crystals structure provided herein. The hypothetical $\mathrm{Au}_{38}\left(\mathrm{SCH}_{3}\right)_{18}$ was established by replacing the central two Ag with Au atoms, followed by structural relaxation. All NCs were modeled with $-\mathrm{SCH}_{3}$ ligands, which kept the accuracy in capturing electronic properties of Au NCs. Linear response TDDFT calculations were performed to obtain the theoretical optical spectra of $\mathrm{Au}_{36} \mathrm{Ag}_{2}\left(\mathrm{SCH}_{3}\right)_{18}, \mathrm{Au}_{38}\left(\mathrm{SCH}_{3}\right)_{18}, \mathrm{Au}_{38}\left(\mathrm{SCH}_{3}\right)_{24}$ and $\mathrm{Au}_{25}\left(\mathrm{SCH}_{3}\right)_{18}{ }^{-} \mathrm{NCs}$. The 700 lowest energy excitations were obtained and fitted using a gaussian broadening half-width of $0.1 \mathrm{eV}$ for all UV-Vis absorption spectra. The contribution to HOMOs and LUMOs was obtained using the natural bond orbital analysis as implemented in Turbomole.

7. Hydrogen Evolution Reaction pathway - Reaction free energy calculations: In order to construct the reaction energy diagram and maintain consistency, electronic structure calculations were performed at the DFT level using the Perdrew-Burke-Ernzerhof (PBE) ${ }^{4}$ functional, Goedecker, Teter, and Hutter (GTH) pseudopotentials, ${ }^{11}$ double- $\zeta$ plus polarization (DZVP) basis set ${ }^{12}$ with a cutoff of 500 Ry as implemented in the computational package $\mathrm{CP} 2 \mathrm{~K} .{ }^{13}$ All systems were optimized in non-periodic cell of dimensions $30 \times$ $30 \times 30 \AA^{3}\left(\right.$ for $\mathrm{Au}_{25}{ }^{-}$) or $32 \times 32 \times 32 \AA^{3}$ (for $\mathrm{Au}_{38}$ and $\mathrm{Au}_{36} \mathrm{Ag}_{2}$ ) until forces were less than $0.02 \mathrm{eV} \mathrm{A}^{-1}$.

The Gibbs free energy for all the systems was calculated using statistical thermodynamics, wherein the vibrational modes were calculated using the harmonic oscillator approximation.

Free energy of $* \mathrm{H}$ adsorption was calculated per equation (1)

$$
\Delta \mathrm{G}=\Delta \mathrm{E}+\Delta \mathrm{E}_{\mathrm{ZPE}}+\int \mathrm{C}_{\mathrm{p}} \mathrm{dT}-\mathrm{T} \Delta \mathrm{S}
$$

where $\Delta \mathrm{E}_{\mathrm{ZPE}}$ represents the Zero Point Energy between the adsorbed $\mathrm{H}$ and $\mathrm{H}$ in the gas phase of $\mathrm{H}_{2}$ molecule, $\mathrm{C}_{\mathrm{p}}$ is heat capacity, $\Delta \mathrm{S}$ is the entropy difference between the adsorbed $\mathrm{H}$ and $1 / 2 \mathrm{H}_{2}$ in the gas phase at standard conditions, and $\Delta \mathrm{E}$ is the electronic energy change of each system. The vibrational modes of only the adsorbate were factored into the free energy calculations. Energy corrections to the $\mathrm{H}_{2}(\mathrm{~g})$ molecule was applied as per the approach of Peterson et al. ${ }^{14}$ The energy of a proton coupled electron transfer was accounted through the concept of the computational hydrogen electrode. ${ }^{15}$

The ease of electron acceptance of a nanocluster is important in explaining the charge transfer behavior during electrocatalysis. We calculated the vertical electron affinity (EA) of each nanocluster as per equation:

$$
E A=E_{N C}^{-1}-E_{N C}^{0}
$$

The EA is calculated as the difference in the electronic energy of the nanocluster with an extra electron and the electronic energy of the nanocluster in its original charge state. For $\mathrm{Au}_{36} \mathrm{Ag}_{2}\left(\mathrm{SCH}_{3}\right)_{18}$ and $\mathrm{Au}_{38}\left(\mathrm{SCH}_{3}\right)_{24}$, EA is calculated using the neutral as the original charge state of the cluster, whereas, for the $\mathrm{Au}_{25}(\mathrm{SR})_{18}$ the negative charge state was used (similar to the experimental charge state). 
8. Supporting figures and tables (in the order of appearance)

Table S1. Crystal data and structure refinement for $\mathrm{Au}_{36} \mathrm{Ag}_{2}\left(\mathrm{SC}_{10} \mathrm{H}_{15}\right)_{18}\left(\mathrm{C}_{6} \mathrm{H}_{5} \mathrm{CH}_{3}\right)_{6}(6$ toluene solvent molecules in the crystal).

Empirical formula

Formula weight

Temperature/K

Crystal system

Space group

$\mathrm{a} / \AA$

$\mathrm{b} / \AA$

$\mathrm{c} / \AA$

$\alpha /^{\circ}$

$\beta /{ }^{\circ}$

$\gamma /{ }^{\circ}$

Volume $/ \AA^{3}$

Z

$\rho_{\text {calc }} \mathrm{g} / \mathrm{cm}^{3}$

$\mu / \mathrm{mm}^{-1}$

$\mathrm{F}(000)$

Crystal size $/ \mathrm{mm}^{3}$

Radiation

$2 \Theta$ range for data collection/ ${ }^{\circ}$

Index ranges

Reflections collected

Independent reflections

Data/restraints/parameters

Goodness-of-fit on $\mathrm{F}^{2}$

Final R indexes $[\mathrm{I}>=2 \sigma(\mathrm{I})]$

Final R indexes [all data]

Largest diff. peak/hole / e $\AA^{-3}$
$\mathrm{Au}_{36} \mathrm{Ag}_{2} \mathrm{~S}_{18} \mathrm{C}_{222} \mathrm{H}_{318}$

10870.36

120(2)

triclinic

P-1

21.822

23.697

24.380

99.34

92.66

94.64

12376.7

2

2.917

41.924

9752.0

$0.03 \times 0.03 \times 0.03$

$\mathrm{CuK} \alpha(\lambda=1.54186)$

7.364 to 124.996

$-25 \leq \mathrm{h} \leq 22,-21 \leq \mathrm{k} \leq 27,-25 \leq 1 \leq 28$

101942

$38708\left[\mathrm{R}_{\mathrm{int}}=0.1114, \mathrm{R}_{\text {sigma }}=0.1484\right]$

$38708 / 2883 / 2461$

1.023

$\mathrm{R}_{1}=0.0824, \mathrm{wR}_{2}=0.1778$

$\mathrm{R}_{1}=0.1627, \mathrm{wR}_{2}=0.2254$

$3.51 /-2.64$ 


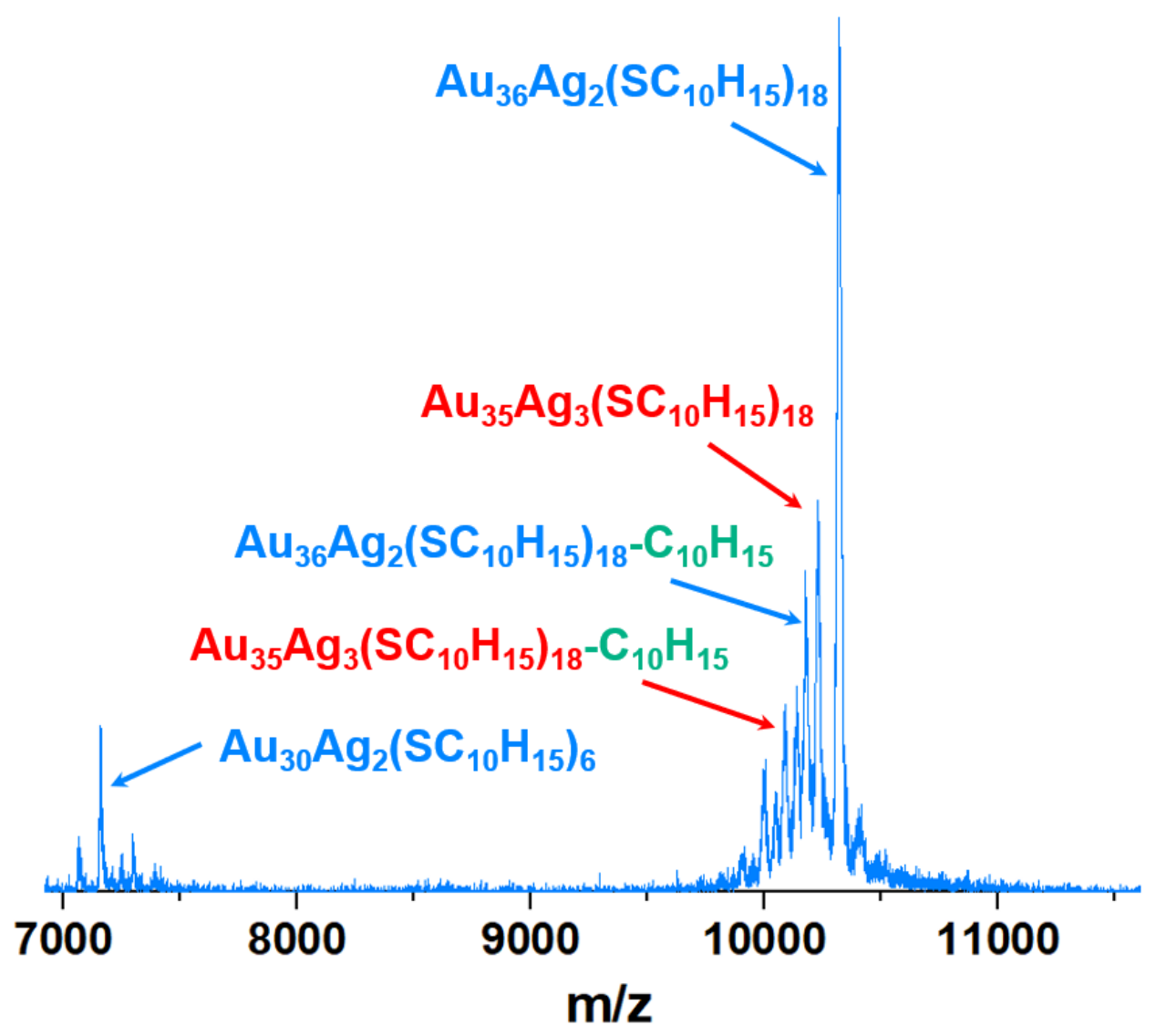

Figure S1. MALDI-MS spectrum of $\mathrm{Au}_{36} \mathrm{Ag}_{2}\left(\mathrm{SC}_{10} \mathrm{H}_{15}\right)_{18} \mathrm{NC}$ in enlarged form. The strongest peak corresponds to $\mathrm{Au}_{36} \mathrm{Ag}_{2}\left(\mathrm{SC}_{10} \mathrm{H}_{15}\right)_{18}$, and its fragment peak of $\mathrm{Au}_{30} \mathrm{Ag}_{2}\left(\mathrm{SC}_{10} \mathrm{H}_{15}\right)_{6}$ with six $\mathrm{Au}\left(\mathrm{SC}_{10} \mathrm{H}_{15}\right)_{2}$ motifs detached in MALDI-MS is observed at lower m/z. A peak of $\mathrm{Au}_{35} \mathrm{Ag}_{3}\left(\mathrm{SC}_{10} \mathrm{H}_{15}\right)_{18}$ is also observed. In addition, peaks corresponding to the detachment of one $\mathrm{C}_{15} \mathrm{H}_{10}$ from $\mathrm{Au}_{36} \mathrm{Ag}_{2}\left(\mathrm{SC}_{10} \mathrm{H}_{15}\right)_{18}$ or $\mathrm{Au}_{35} \mathrm{Ag}_{3}\left(\mathrm{SC}_{10} \mathrm{H}_{15}\right)_{18}$ are also observed. 
a LUMO
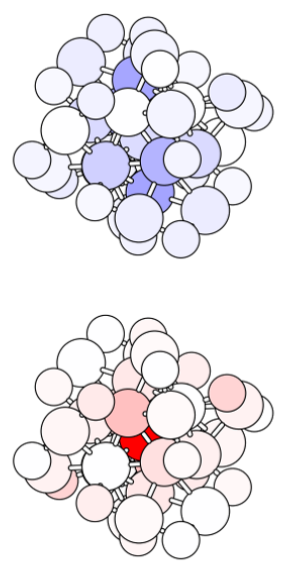

номо
LUMO+1
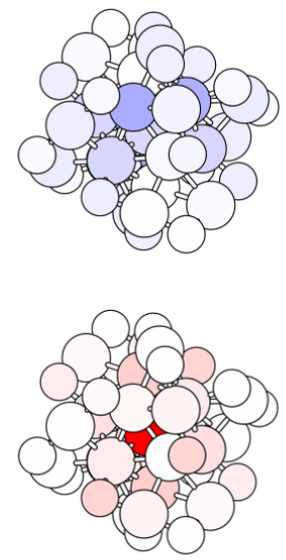

HOMO-1
LUMO+2
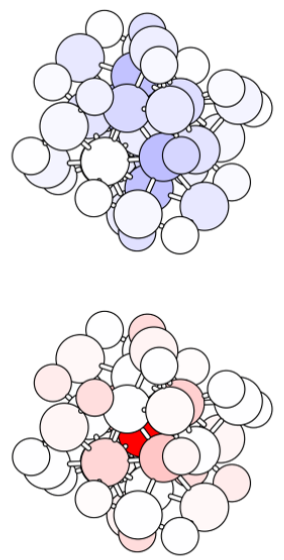

HOMO-2
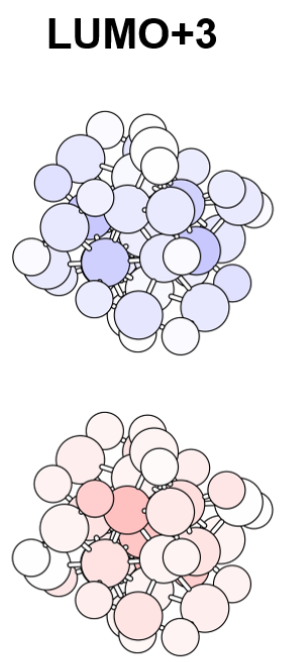

HOMO-3

Strong

contribution

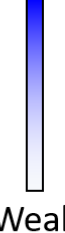

contribution

Strong

contribution

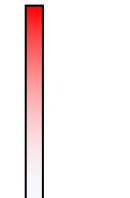

Weak contribution

LUMO+2
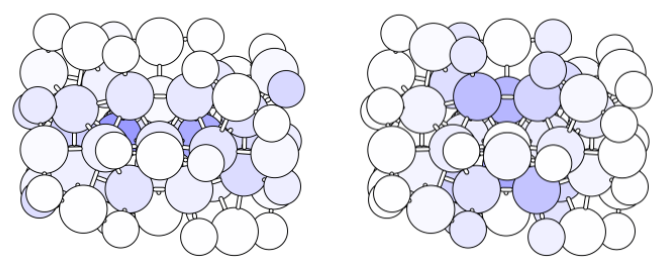

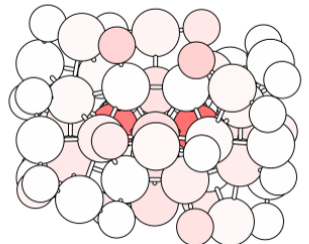

HOMO-2

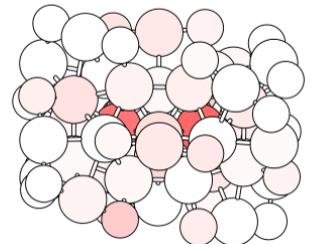

HOMO-3
Weak contribution

Strong contribution

Strong contribution

contribution
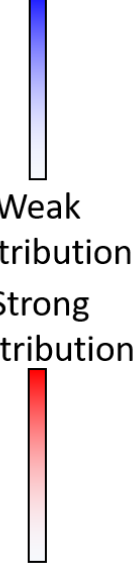

Weak contribution

Figure S2. (a) The contributions from different atoms to the KS frontier orbitals from HOMO-3 to LUMO+3 for $\left[\mathrm{Au}_{25}\left(\mathrm{SCH}_{3}\right)_{18}\right]^{-}$. (b) The contributions from different atoms to the KS frontier orbitals from HOMO-3 to LUMO+3 for $\mathrm{Au}_{38}\left(\mathrm{SCH}_{3}\right)_{24}$. Contribution is indicated by color, blue for LUMOs and red for HOMOs (darker for stronger contribution and lighter for weaker contribution). 


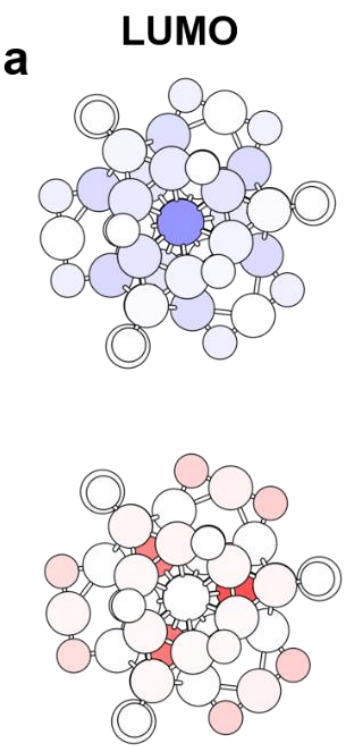

HOMO
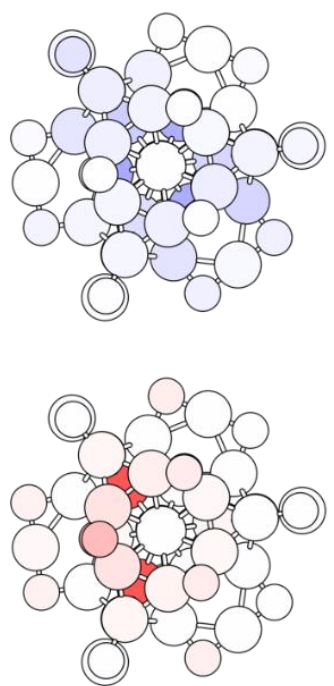

HOMO-1
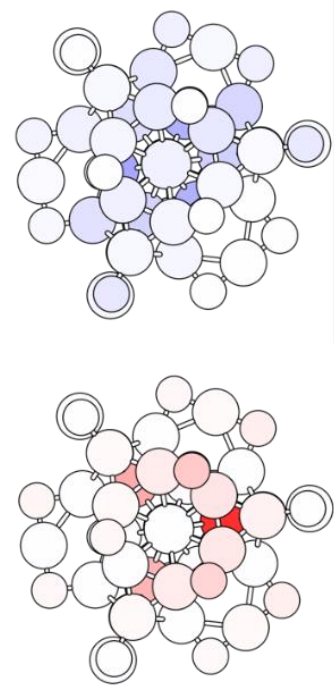

HOMO-2
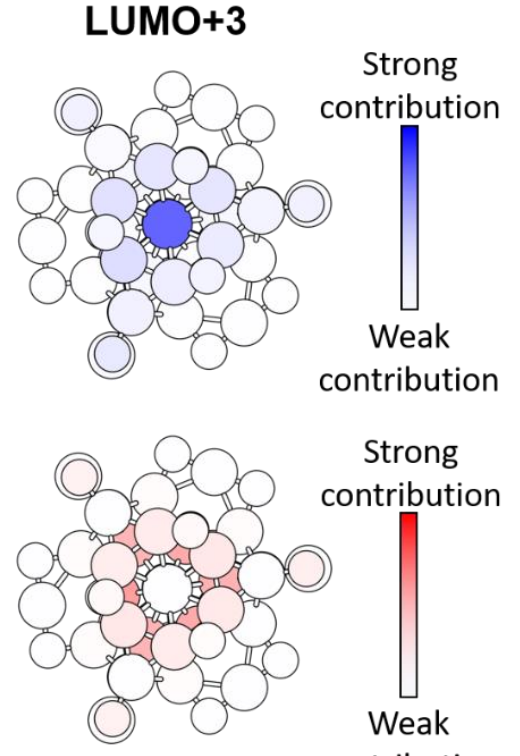

HOMO-3
Strong

contribution

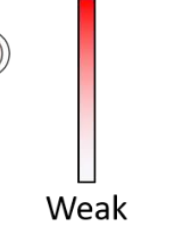

contribution
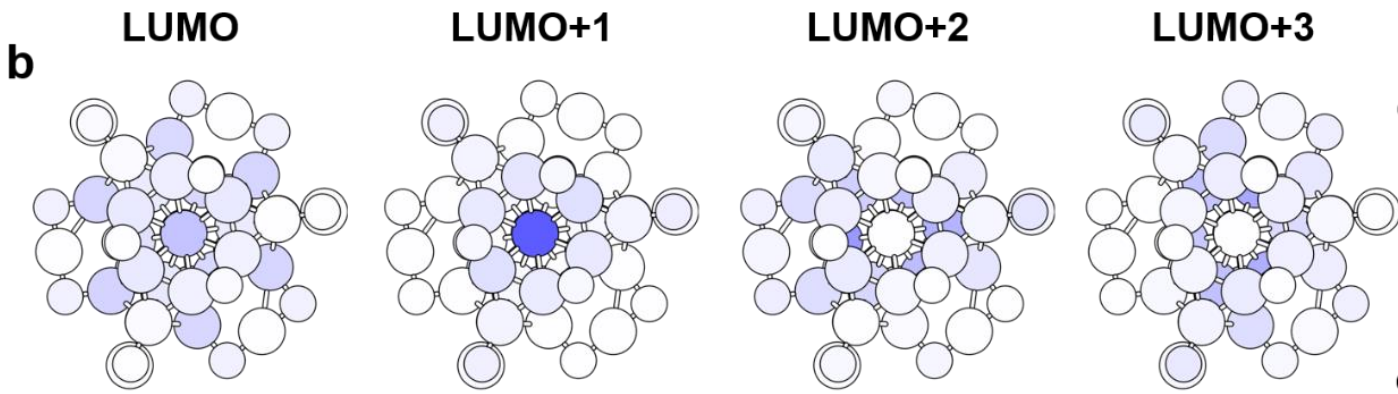

Strong

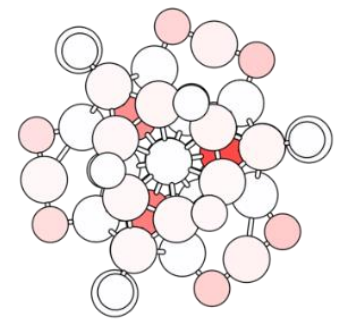

HOMO

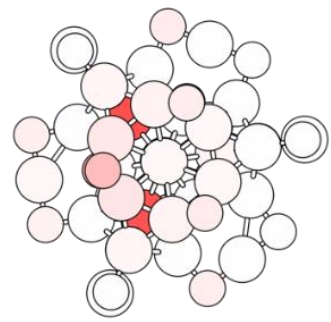

HOMO-1

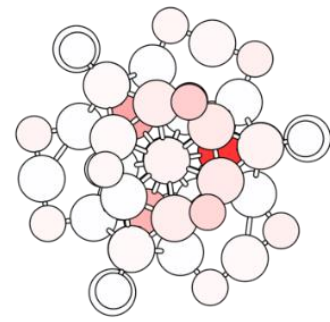

HOMO-2

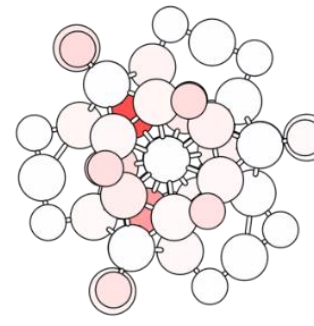

HOMO-3 contribution

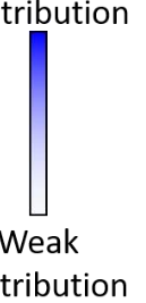

contribution

Strong contribution

Weak contribution

Figure S3. (a) The contributions from different atoms to the KS frontier orbitals from HOMO-3 to LUMO+3 for $\mathrm{Au}_{36} \mathrm{Ag}_{2}\left(\mathrm{SCH}_{3}\right)_{18}$. (b) The contributions from different atoms to the KS frontier orbitals from HOMO-3 to LUMO+3 for hypothetical $\mathrm{Au}_{38}\left(\mathrm{SCH}_{3}\right)_{18}$. Contribution is indicated by color, blue for LUMOs and red for HOMOs (darker for stronger contribution and lighter for weaker contribution). 

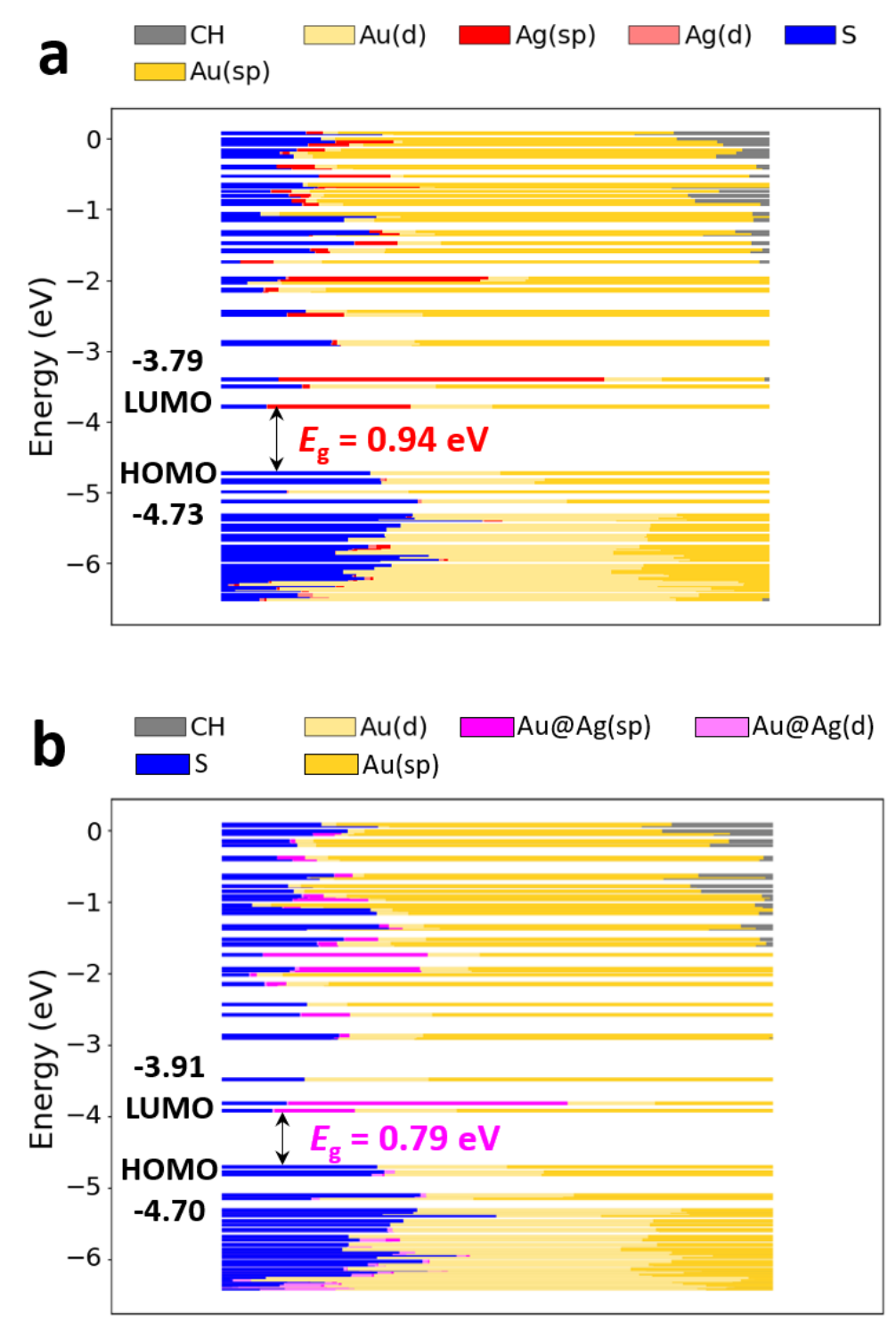

Figure S4. (a) KS orbital energy level diagram for $\mathrm{Au}_{36} \mathrm{Ag}_{2}\left(\mathrm{SCH}_{3}\right)_{18}$. (b) $\mathrm{KS}$ orbital energy level diagram for $\mathrm{Au}_{38}\left(\mathrm{SCH}_{3}\right)_{18}$ with two $\mathrm{Au}$ atoms at the $\mathrm{Ag}$ positions in $\mathrm{Au}_{36} \mathrm{Ag}_{2}\left(\mathrm{SCH}_{3}\right)_{18}$ being highlighted as $\mathrm{Au} @ \mathrm{Ag}$. Each KS orbital character is drawn to indicate the relative contributions (line length with color labels) of the atomic orbitals. 


\section{$\mathrm{Au}_{36} \mathrm{Ag}_{2}\left(\mathrm{SCH}_{3}\right)_{18}$}

\section{$\mathrm{BF}_{3}$}
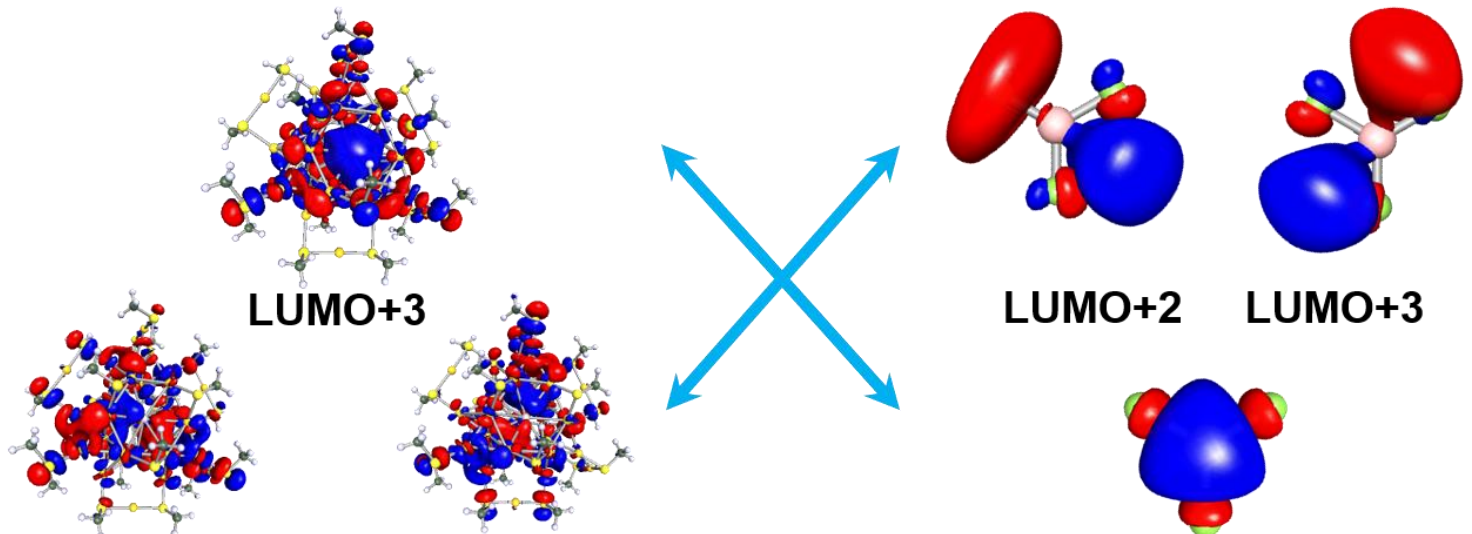

LUMO+2 LUMO+3

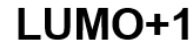

LUMO+2

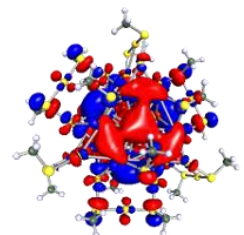

LUMO

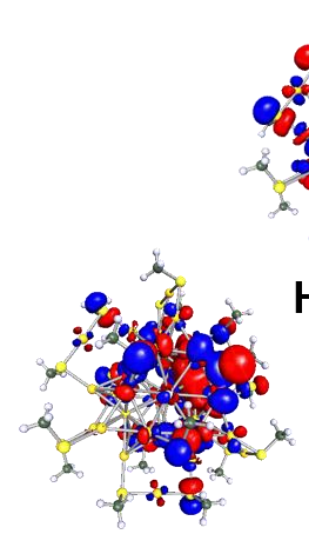

HOMO-1

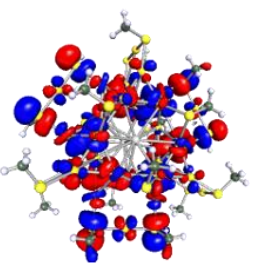

HOMO

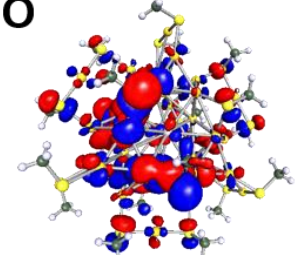

HOMO-2

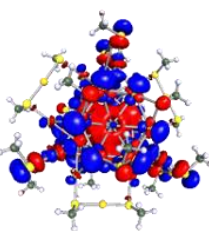

HOMO-3

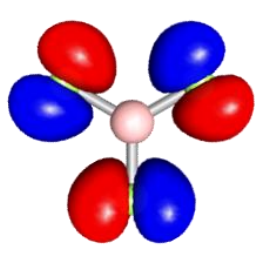

HOMO

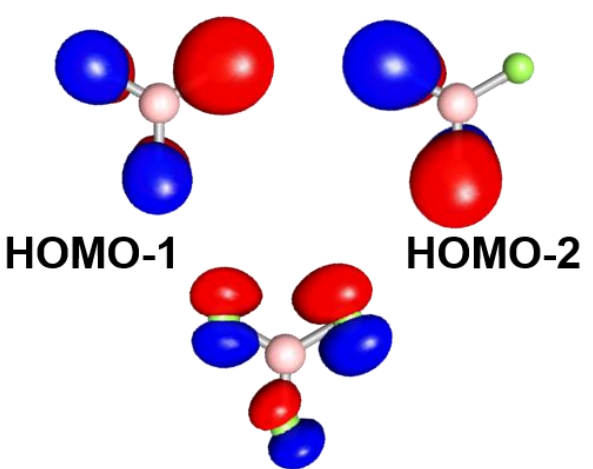

HOMO-3

Figure S5. The KS diagrams for the frontier orbitals of $\mathrm{Au}_{36} \mathrm{Ag}_{2}\left(\mathrm{SCH}_{3}\right)_{18}$ and $\mathrm{BF}_{3}$. The order shift in $\mathrm{LUMO}+1 / \mathrm{LUMO}+2$ and $\mathrm{LUMO}+3$ of $\mathrm{Au}_{36} \mathrm{Ag}_{2}\left(\mathrm{SCH}_{3}\right)_{18}$ compared to $\mathrm{BF}_{3}$ is indicated by arrows. 


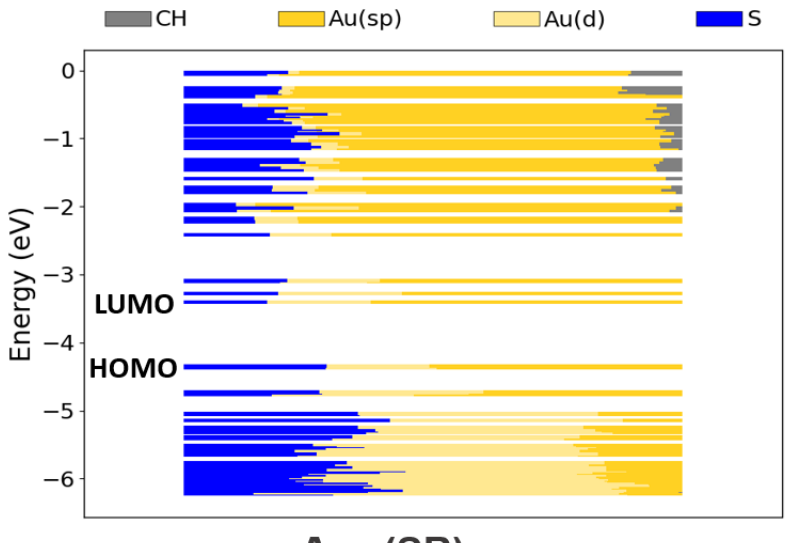

$\mathrm{Au}_{38}(\mathrm{SR})_{24}$

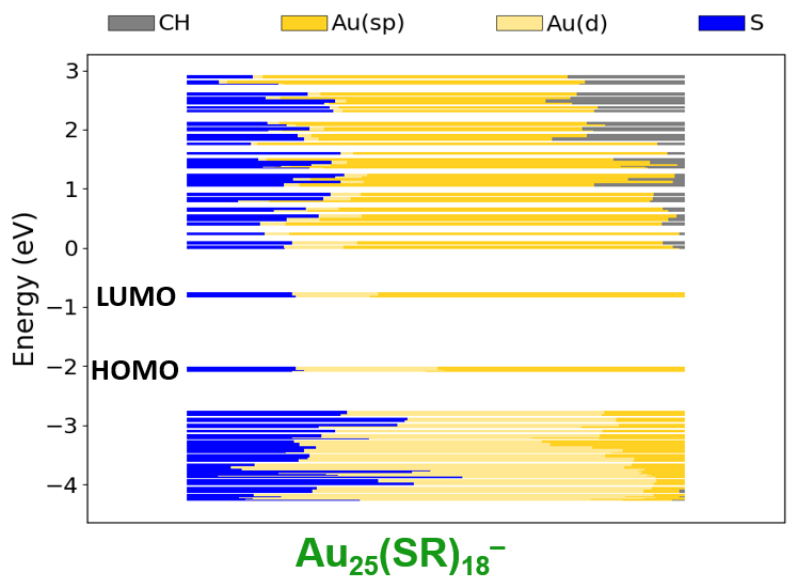

Figure S6. KS orbital energy level diagrams.
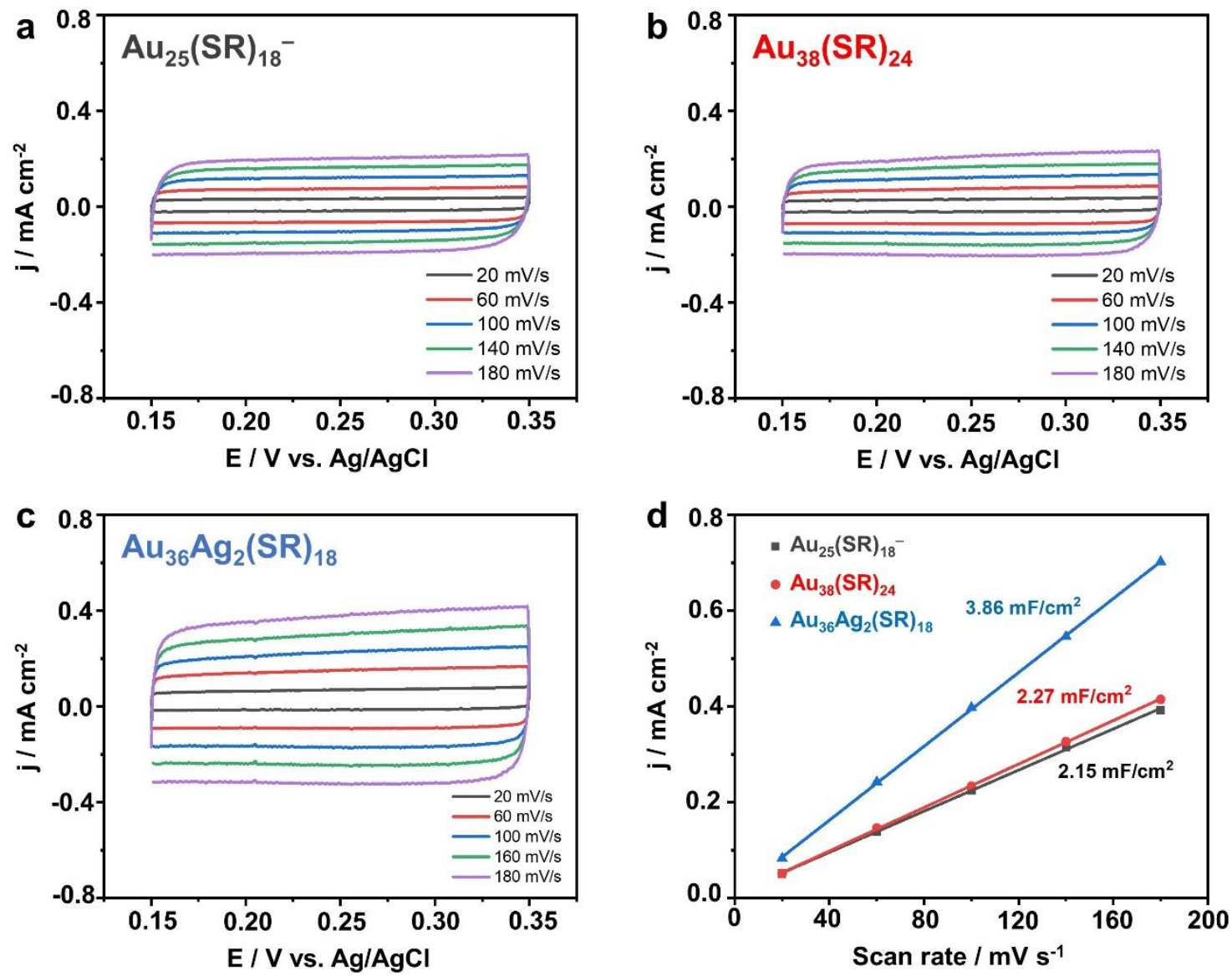

Figure S7. Voltammograms of (a) $\mathrm{Au}_{25}(\mathrm{SR})_{18}{ }^{-}$, (b) $\mathrm{Au}_{38}(\mathrm{SR})_{24}$ and (c) $\mathrm{Au}_{36} \mathrm{Ag}_{2}(\mathrm{SR})_{18}$ electrocatalysts at various scan rates (20 to $180 \mathrm{mV} / \mathrm{s}$ ). (d) Plot of the current density at $0.25 \mathrm{~V}$ against the scan rate. The electrochemical double-layer capacitances, equivalent to the linear slopes in (d), are used to compare the ECSA of the electrocatalysts. 


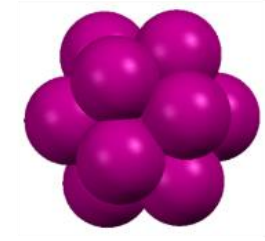

$\mathrm{Au}_{12}$

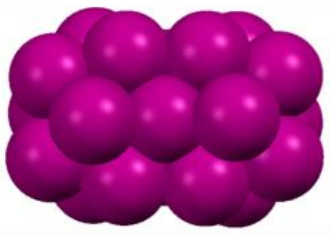

$\mathrm{Au}_{21}$

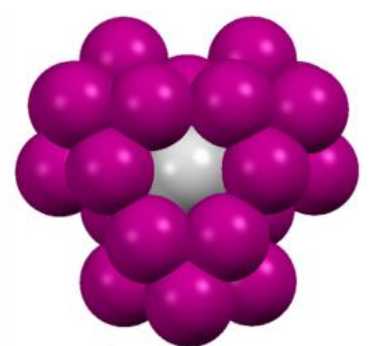

$\mathrm{Au}_{27} \mathrm{Ag}_{2}$
$\mathbf{N}_{\text {surf. }}=4.89 * 10^{17}$
$5.87 * 10^{17}$
$8.46 * 10^{17}$

Figure S8. The kernel surface atoms of NCs. (left) $\mathrm{Au}_{12}$ shell of $\mathrm{Au}_{25}(\mathrm{SR})_{18}$, (middle) $\mathrm{Au}_{21}$ shell of $\mathrm{Au}_{38}(\mathrm{SR})_{24}$, and (right) $\mathrm{Au}_{27} \mathrm{Ag}_{2}$ shell of $\mathrm{Au}_{36} \mathrm{Ag}_{2}(\mathrm{SR})_{18}$. The surface atom number are calculated by the equation of $0.5 \mathrm{mg} / 7394.2 \mathrm{~mol} \mathrm{mg}^{-1} \times 6.02 \times 10^{23} \mathrm{~mol}^{-1} \times 12=4.89 \times 10^{17}$ for $\mathrm{Au}_{25}(\mathrm{SR})_{18} ; 0.5 \mathrm{mg} /$ $10778.1 \mathrm{~mol} \mathrm{mg}^{-1} \times 6.02 \times 10^{23} \mathrm{~mol}^{-1} \times 21=5.87 \times 10^{17}$ for $\mathrm{Au}_{38}(\mathrm{SR})_{24}$; and $0.5 \mathrm{mg} / 10316.3 \mathrm{~mol} \mathrm{mg}^{-1} \times$ $6.02 \times 10^{23} \mathrm{~mol}^{-1} \times 29=8.46 \times 10^{17}$ for $\mathrm{Au}_{36} \mathrm{Ag}_{2}(\mathrm{SR})_{18}$.

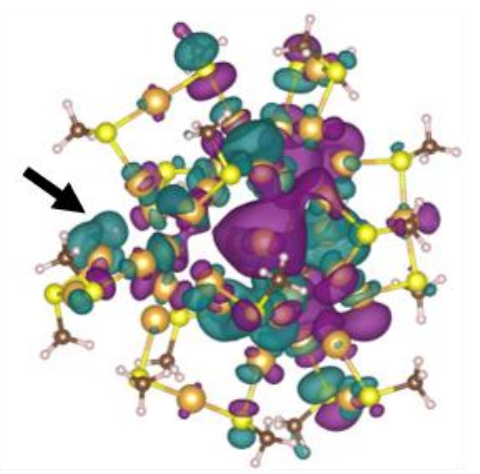

$\mathrm{Au}_{38}\left(\mathrm{SCH}_{3}\right)_{18}$

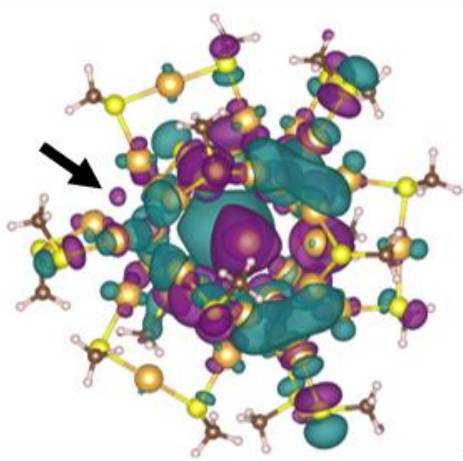

\section{LUMO}

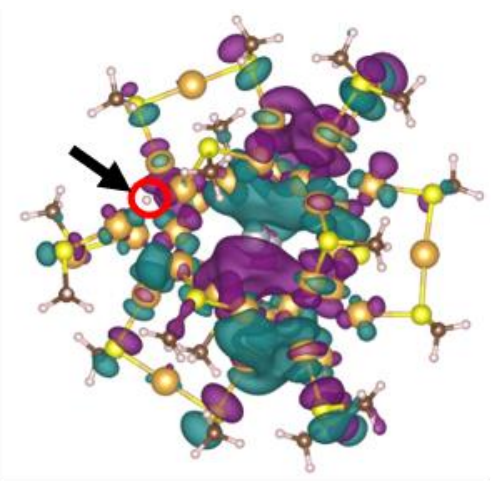

\section{$\mathrm{Au}_{36} \mathrm{Ag}_{2}\left(\mathrm{SCH}_{3}\right)_{18}$}

HOMO

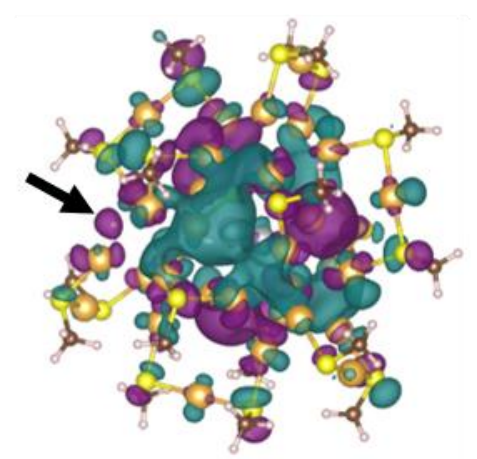

Figure S9. $\mathrm{HOMO}$ and $\mathrm{LUMO}$ of $\mathrm{Au}_{38}\left(\mathrm{SCH}_{3}\right)_{18}$ and $\mathrm{Au}_{36} \mathrm{Ag}_{2}\left(\mathrm{SCH}_{3}\right)_{18}$ with $* \mathrm{H}$ adsorbed on their surface. 
Table S2. The formulas of reported $\mathrm{Au}_{n}(\mathrm{SR})_{m}$ or Au-based $\mathrm{M}_{n}(\mathrm{SR})_{m}$.

\begin{tabular}{ccc}
\hline & $\mathrm{Au}_{n}(\mathrm{SR})_{m}$ & \\
\hline $\mathrm{Au}_{16}(\mathrm{SR})_{12}$ & $\mathrm{Au}_{18}(\mathrm{SR})_{14}$ & $\mathrm{Au}_{20}(\mathrm{SR})_{16}$ \\
\hline $\mathrm{Au}_{21}(\mathrm{SR})_{15}$ & $\mathrm{Au}_{23}(\mathrm{SR})_{16}$ & $\mathrm{Au}_{24}(\mathrm{SR})_{16}$ \\
\hline $\mathrm{Au}_{25}(\mathrm{SR})_{18}$ & $\mathrm{Au}_{28}(\mathrm{SR})_{20}$ & $\mathrm{Au}_{30}(\mathrm{SR})_{18}$ \\
\hline $\mathrm{Au}_{34}(\mathrm{SR})_{22}$ & $\mathrm{Au}_{36}(\mathrm{SR})_{24}$ & $\mathrm{Au}_{38}(\mathrm{SR})_{24}$ \\
\hline $\mathrm{Au}_{40}(\mathrm{SR})_{24}$ & $\mathrm{Au}_{42}(\mathrm{SR})_{26}$ & $\mathrm{Au}_{43}(\mathrm{SR})_{25}$ \\
\hline $\mathrm{Au}_{44}(\mathrm{SR})_{28}$ & $\mathrm{Au}_{48}(\mathrm{SR})_{28}$ & $\mathrm{Au}_{49}(\mathrm{SR})_{27}$ \\
\hline $\mathrm{Au}_{52}(\mathrm{SR})_{32}$ & $\mathrm{Au}_{64}(\mathrm{SR})_{32}$ & $\mathrm{Au}_{76}(\mathrm{SR})_{44}$ \\
\hline $\mathrm{Au}_{92}(\mathrm{SR})_{44}$ & $\mathrm{Au}_{102}(\mathrm{SR})_{44}$ & $\mathrm{Au}_{130}(\mathrm{SR})_{50}$ \\
\hline $\mathrm{Au}_{133}(\mathrm{SR})_{52}$ & $\mathrm{Au}_{144}(\mathrm{SR})_{60}$ & $\mathrm{Au}_{146}(\mathrm{SR})_{57}$ \\
\hline $\mathrm{Au}_{191}(\mathrm{SR})_{66}$ & $\mathrm{Au}_{246}(\mathrm{SR})_{80}$ & \\
\hline & $\mathrm{Au} \mathbf{b a s e d ~}_{20}(\mathrm{SR})_{84}$ \\
\hline $\mathrm{Au}_{14} \mathrm{Cd}_{1}(\mathrm{SR})_{12}$ & $\mathrm{Au}_{16} \mathrm{Ag}_{1}(\mathrm{SR})_{13}$ & \\
\hline $\mathrm{Au}_{20} \mathrm{Ag}_{1}(\mathrm{SR})_{15}$ & $\mathrm{Au}_{19} \mathrm{Ag}_{4}(\mathrm{SR})_{15}$ & $\mathrm{Au}_{19} \mathrm{Cd}_{2}(\mathrm{SR})_{16}$ \\
\hline $\mathrm{Au}_{12} \mathrm{Ag}_{32}(\mathrm{SR})_{30}$ & $\mathrm{Au}_{26} \mathrm{Ag}_{22}(\mathrm{SR})_{30}$ & $\mathrm{Au}_{24} \mathrm{Cu}_{6}(\mathrm{SR})_{22}$ \\
\hline $\mathrm{Au}_{52} \mathrm{Cu}_{72}(\mathrm{SR})_{55}$ & $\mathrm{Au}_{267-x} \mathrm{Ag}_{x}(\mathrm{SR})_{80}$ & $\mathrm{Au}_{24} \mathrm{Ag}_{46}(\mathrm{SR})_{32}$ \\
\hline
\end{tabular}

\section{Supporting references}

(1) Dolomanov, O. V.; Bourhis, L. J.; Gildea, R. J.; Howard, J. A.; Puschmann, H. OLEX2: A Complete Structure Solution, Refinement and Analysis Program. J. Appl. Cryst. 2009, 42, 339-341.

(2) Bourhis, L. J.; Dolomanov, O. V.; Gildea, R. J.; Howard, J. A.; Puschmann, H. The Anatomy of a Comprehensive Constrained, Restrained Refinement Program for the Modern Computing Environment Olex2 Dissected. Acta. Cryst. 2015, A71, 59-75.

(3) Sheldrick, G. M. SHELXT - Integrated Space-Group and Crystal-Structure Determination. Acta. Cryst. 2015, A71, 3-8.

(4) Perdew, J. P.; Burke, K.; Ernzerhof, M. Generalized Gradient Approximation Made Simple. Phys. Rev. Lett. 1996, 77, 3865-3868.

(5) Weigend, F.; Häser, M.; Patzelt, H.; Ahlrichs, R. RI-MP2: Optimized Auxiliary Basis Sets and Demonstration of Efficiency. Chemical Physics Letters 1998, 294, 143-152.

(6) Feyereisen, M.; Fitzgerald, G.; Komornicki, A. Use of Approximate Integrals in Ab Initio Theory. An Application in MP2 Energy Calculations. Chemical Physics Letters 1993, 208, 359-363. 
(7) Weigend, F.; Häser, M. RI-MP2: First Derivatives and Global Consistency. Theoretical Chemistry Accounts 1997, 97, 331-340.

(8) Ahlrichs, R.; Bär, M.; Häser, M.; Horn, H.; Kölmel, C. Electronic Structure Calculations on Workstation Computers: The Program System Turbomole. Chemical Physics Letters 1989, 162, 165-169.

(9) Zhu, M.; Aikens, C. M.; Hollander, F. J.; Schatz, G. C.; Jin, R. Correlating the Crystal Structure of a ThiolProtected $\mathrm{Au}_{25}$ Cluster and Optical Properties. J. Am. Chem. Soc. 2008, 130, 5883-5885.

(10) Qian, H.; Eckenhoff, W. T.; Zhu, Y.; Pintauer, T.; Jin, R. Total Structure Determination of ThiolateProtected $\mathrm{Au}_{38}$ Nanoparticles. J. Am. Chem. Soc. 2010, 132, 8280-8281.

(11) Goedecker, S.; Teter, M.; Hutter, J. Separable Dual-Space Gaussian Pseudopotentials. Phys. Rev. B 1996, 54, 1703-1710.

(12) VandeVondele, J.; Hutter, J. Gaussian Basis Sets for Accurate Calculations on Molecular Systems in Gas and Condensed Phases. J. Chem. Phys. 2007, 127, 114105.

(13) VandeVondele, J.; Krack, M.; Mohamed, F.; Parrinello, M.; Chassaing, T.; Hutter, J. Quickstep: Fast and Accurate Density Functional Calculations Using a Mixed Gaussian and Plane Waves Approach. Computer Physics Communications 2005, 167, 103-128.

(14) Peterson, A. A.; Abild-Pedersen, F.; Studt, F.; Rossmeisl, J.; Nørskov, J. K. How Copper Catalyzes the Electroreduction of Carbon Dioxide into Hydrocarbon Fuels. Energy Environ. Sci. 2010, 3, 1311-1315.

(15) Nørskov, J. K.; Rossmeisl, J.; Logadottir, A.; Lindqvist, L.; Kitchin, J. R.; Bligaard, T.; Jónsson, H. Origin of the Overpotential for Oxygen Reduction at a Fuel-Cell Cathode. J. Phys. Chem. B 2004, 108, 1788617892. 